Journal of Telenursing (JOTING)

Volume 1, Nomor 1, Juni 2019

e-ISSN : 2684-8988

p-ISSN : 2684-8996

DOI: https://doi.org/10.31539/joting.v1i1.493

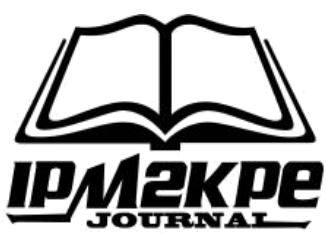

\title{
PERBANDINGAN PEMBERIAN HIPEROKSIGENASI SATU MENIT DAB DUA MENIT PADA PROSES SUCTION TERHADAP SATURASI OKSIGEN PASIEN TERPASANG VENTILATOR
}

\author{
Teti Hayati ${ }^{1}$, Busjra M Nur ${ }^{2}$, Fitrian Rayasari ${ }^{3}$, Yani Sofiani ${ }^{4}$, Diana Irawati ${ }^{5}$ \\ Akademi Perawat RSPAD Gatot soebroto ${ }^{1}$ \\ Universitas Muhammadiyah Jakarta $2,3,4,5$ \\ tetihayati102@gmail.com ${ }^{1}$
}

\begin{abstract}
ABSTRAK
Penelitian ini bertujuan untuk mengidentifikasi adanya pengaruh pemberian hiperoksigenasi 1 menit pada proses suctioning terhadap saturasi oksigen pasien dengan ventilator mekanik. Desain penelitian quasi eksperimen pre-post test dengan control group design. Hasil penelitian menunjukkan saturasi oksigen intervensi I sebelum hiperoksigenasi median 97 min-mak 95-99, setelah dilakukan hiperoksigenasi median 99 min-mak 98-100 dengan $\mathrm{p}$ value 0,05. Sedangkan pada kelompok intervensi II sebelum hiperoksigenasi median 97 min-mak 95-100, setelah hiperoksigenasi median 99 min-mak 95-100, dengan $p$ value 0,05. Simpulan, terdapat perbedaan saturasi oksigen yang signifikan sebelum dan setelah pemberian hiperoksigenasi 1 menit.
\end{abstract}

Kata Kunci : Hiperoksigenasi, Proses Suction, Saturasi Oksigen, Ventilator

\section{ABSTRACT}

This study aims to identify the effect of 1 minute hyperoxygenation on the suctioning process on oxygen saturation of patients with mechanical ventilators. Quasi experimental research design pre-post test with control group design. The results showed oxygen I saturation before median hyperoxygenation $97 \mathrm{~min}$ 95-99, after median hyperoxygenation 99 min 98-100 with $p$ value 0.05. While in the intervention group II before median hyperoxygenation $97 \mathrm{~min}$ 95-100, after median hyperoxygenation $99 \mathrm{~min}$ 95-100, with $p$ value 0.05. In conclusions there were significant differences in oxygen saturation before and after 1 minute hyperoxygenation administration.

Keywords: Hyperoxygenation, Suction Process, Oxygen Saturation, Ventilator

\section{PENDAHULUAN}

Insidensi Acute Respiratory Distress Syndrome (ARDS) pada The AmericanEuropean Consensus on ARDS tahun 2010 menemukan antara 12,6-28,0 kasus/100.000 penduduk/tahun serta dilaporkan sekitar $40 \%$ terjadi kematian akibat gagal napas. Insidensi gagal napas akut pada dewasa dari hasil studi di negara Jerman dan Swedia melaporkan bahwa 77,6-88,6 kasus/100.000 penduduk/tahun. Data dari Kementerian Kesehatan RI, 2012 yang terfatal menyebabkan kematian berdasarkan data peringkat 10 Penyakit Tidak Menular (PTM) pada tahun 2010, Case Fatality Rate (CFR) angka 
kejadian gagal napas pada pasien rawat inap dirumah sakit yaitu sebesar 20,98\% menempati peringkat kedua.

Berdasarkan data dari buku registrasi pasien di ICU RSPAD Gatot Soebroto Puskesad dari bulan Januari sampai dengan bulan Desember 2017 banyaknya pasien di ruang ICU berjumlah 2.277 pasien dan sebanyak 807 pasien $(35,44 \%)$ mengalami kejadian gagal napas. Bila dirata-ratakan perbulannya adalah 189-190 pasien yang dirawat di ICU. Yang mengalami kejadian gagal napas sebanyak 67-68 pasien/bulan dan pasien yang meninggal sebanyak 29-30 pasien/bulan (ICU RSPAD Gatot Soebroto, 2018).

Intensive Care Unit (ICU) adalah suatu ruangan untuk merawat pasien dirumah sakit yang mempunyai staf dan perlengkapan khusus yang ditujukan untuk pengelolahan pasien yang mengalami komplikasi yang mengancam jiwa, penyakit, atau trauma. Perlengkapan peralatan di Intensive Care Unit (ICU) mempunyai standar meliputi alat untuk membantu usaha bernafas melalui Endotrakeal Tube (ETT) yang tersambung dengan ventilasi mekanik. Indikasi dari pemasangan alat ventilasi mekanik salah satunya adalah gagal nafas (Musliha, 2010). Dikatakan gagal napas bilamana pertukaran oksigen atau $\mathrm{O}_{2}$ terhadap karbondioksida atau $\mathrm{CO}_{2}$ didalam organ paru paru tidak dapat memelihara laju $\mathrm{O}_{2}$ dan $\mathrm{CO}_{2}$ didalam sel-sel tubuh manusia. Sehingga peningkatan tekanan $\mathrm{CO}_{2}$ lebih besar ${ }_{1}$ dari $45 \mathrm{mmHg}$ atau hiperkapnia dan tekanan $\mathrm{O}_{2}$ arteri kurang dari $50 \mathrm{mmHg}$ atau hipoksemia.

Endotracheal Tube (ETT) merupakan konektor yang digunakan untuk ventilasi mekanik. Ventilasi mekanik yang digunakan adalah ventilasi mekanik invasif. ETT yang telah terpasang memerlukan perhatian khusus dalam menjaga kebersihan dari akumulasi sekret, sehingga patensi jalan nafas menjadi tetap terjaga. Untuk menjaga kepatenan jalan nafas akibat penumpukan sekresi tersebut, tindakan yang dilakukan adalah penghisapan lendir (suctioning). Melakukan tindakan suction yaitu dengan cara selang kateter suction dimasukkan melalui hidung, mulut pada ETT (Nurachmah \& Sudarsono, 2010). Tindakan suction dilakukan untuk membersihkan jalan nafas dari sekret atau sputum dan juga untuk menghindari dari infeksi jalan nafas (Price \& Wilson, 2012).

Selain untuk mengatasi masalah bersihan jalan nafas, tindakan suction sangat diperlukan, karena pada pasien terpasang ventilasi mekanik terjadi kontaminasi mikroba dijalan nafas dan berkembangnya Ventilator Assosiated Pnemonia (VAP) (Kozier \& Erb, 2012). Terjadinya VAP dikarenakan secara umum pasien yang terpasang ETT mempunyai respon tubuh yang sangat lemah untuk batuk, dengan demikian tindakan suction sangat diperlukan (Nurachmah \& Sudarsono, 2010).

Pada saat akan melakukan tindakan suction pada ETT, sangatlah perlu adanya pemantauan saturasi oksigen, karena saat tindakan suction bukan hanya sekret yang terhisap, tetapi oksigen juga terhisap. Selain itu saturasi oksigen pada tindakan suction dipengaruhi oleh banyaknya hiperoksigenasi yang diberikan, tekanan suction yang sesuai usia, dan besar diameter kanule. Bila hal tersebut tidak atau kurang diperhatikan maka akan menimbulkan komplikasi. Komplikasi dari suction pada pasien yang terpasang ventilasi mekanik adalah terjadinya hipoksia yang ditandai dengan penurunan saturasi oksigen atau desaturasi (Kozier \& Erb, 2012). Menurut Wiyoto (2010) apabila suplai oksigen dalam waktu 4 menit tidak terpenuhi untuk suplai keotak maka otak terjadi kerusakan yang permanen, karena itu perlu dilakukan hiperoksigenasi sebelum dilakukan suction. Upaya untuk mempertahankan saturasi oksigen setelah dilakukan suction adalah dengan melakukan hiperoksigenasi pada setiap tindakan suction. 
Hiperoksigenasi adalah pemberian oksigen konsentrasi tinggi (100\%) yang bertujuan untuk menghindari hipoksemi akibat suction (Kozier \& Erb, 2012). Teknik yang terbaik didalam menghindari hipoksemia yang diakibatkan tindakan suction adalah dengan hiperoksigenasi. Dengan demikian pada semua prosedur suction, tindakan hiperoksigenasi harus dilaksanakan (Kozier \& Erb, 2012). Penelitian yang dilakukan G.M. Superdana dan Sumara tahun 2015 diruang ICU Rumah Sakit Husada Utama Surabaya yang berjudul efektifitas hiperoksigenasi pada proses suctioning terhadap saturasi oksigen pasien dengan ventilator mekanik, menyimpulkan hiperoksigenasi efektif pada proses suctioning terhadap saturasi oksigen pasien dengan ventilator mekanik, dengan $\mathrm{P}<0,005$.

Penelitian yang dilakukan Moraveji et al., (2012) di ICU menunjukkan bahwa hiperoksigenasi yang dilakukan satu menit selama suction menyebabkan perbaikan dan pencegahan hipoksia yang disebabkan prosedur suction. Menurut Hudak \& Gallo (2013) mengatakan komplikasi dari pemberian oksigen adalah : membrane mukosa menjadi kering, epistaksis, atau infeksi pada lubang hidung. Bila dalam waktu lama dapat menyebabkan toksisitas yang tinggi (dapat dilihat pada kasus cedera paru akut atau sindrom pada gawat nafas akut), atelectasis absorbtif.

Hasil wawancara dengan penanggung jawab diklat ICU RSPAD menyampaikan pada Standar Operating Prosedure (SOP) suctioning di ICU RSPAD pemberian hiperoksigenasi pre suction sebanyak 2 menit dan hiperoksigenasi diberikan lagi 2 menit bila saturasioksigen post suction $<95 \%$. Untuk tindakan suction dilakukan selama 15 detik. Hal ini tidak tepat karena pemberian hiperoksigenasi maksimal diberikan 2 menit pada prosedur suction. Untuk tindakan suction harusnya dilakukan maksimal 10 detik, karena bila lebih dari 10 detik beresiko terjadi hipoksia (Kozier \& Erb, 2012). Pemberian hiperoksigenasi menurut peneliti yang efisien dan tidak terjadi hipoksia adalah hiperoksigenasi diberikan 30 detik pre suction, suction 10 detik hiperoksigenasi 30 detik. Berdasarkan data-data tersebut peneliti ingin melihat perbandingan pemberian hiperoksigenasi satu menit dan dua menit pada tindakan suctioning terhadap saturasi oksigen pasien dengan ventilasi mekanik di Intensive Care Unit RSPAD Gatot Soebroto Puskesad.

Dalam Saskatoon Health regional Authority (2010) mengatakan bahwa komplikasi yang muncul dari tindakan penghisapan sekret salah satunya adalah hipoksemia atau hipoksia. Penelitian yang dilakukan oleh Wijaya (2015) berjudul Perubahan Saturasi Oksigen Pada Pasien Kritis Yang Dilakukan Tindakan Suction Endotracheal Tube di ICU RSUD DR. Moewardi Surakarta dengan kesimpulan tindakan suction pada pasien yang terpasang endotracheal tube dapat menyebabkan penurunan saturasi oksigen antara 4-10\%.

Apabila suplai oksigen dalam waktu 4 menit tidak terpenuhi untuk suplai keotak maka otak terjadi kerusakan yang permanen dan sangat mengancam jiwa. Oleh karena itu perawat perlu melakukan hiperoksigenasi sebelum melakukan tindakan suction. Pemberian hiper oksigenasi di ruang ICU RSPAD pada SOP pemberian hiperoksigenasi pre suction diberikan 2 menit, pengisapan suction selama 15 detik. Oleh karena itulah, rumusan masalah yang dapat diangkat adalah bagaimana perbandingan pemberian hiperoksigenasi satu menit dan dua menit pada proses suctioning terhadap saturasi oksigen pasien dengan ventilasi mekanik di Intensive Care Unit RSPAD Gatot Soebroto Puskesad. 


\section{METODE PENELITIAN}

Penelitian ini adalah desain penelitian kuantitatif dengan menggunakan metode quasi eksperimen, menggunakan tehnik consecutive sampling menggunakan rancangan pre test dan post test dimana kelompok A disebut kelompok intervensi I yang memperoleh hiperoksigenasi 1 menit, sedangkan kelompok B disebut sebagai kelompok intervensi II dengan pemberian hiperoksigenasi sesuai yang dilakukan diruang ICU RSPAD Gatot Soebroto Puskesad.

Jumlah sampel untuk setiap kelompok intervensi sebanyak 17 sampel. Jadi seluruh jumlah sampel pada penelitian ini adalah sebanyak 34 orang responden. Tempat penelitian dilakukan di diruang ICU RSPAD Gatot Soebroto Puskesad, dilaksanakan pada tanggal 16 Mei sampai dengan 02 Juli 2018.

\section{Alat Pengumpulan Data Pengukuran Saturasi Oksigen}

Untuk hasil pengukuran saturasi Oksigen akan dicantumkan pada lembar observasi (Formulir Observasi). Saturasi Oksigen merupakan suatu alat yang berfungsi untuk mengetahui kadar oksigen di dalam darah, dapat diukur menggunakan oksimetri nadi. Cara kerja oksimetri nadi dengan melakukan pengukuran diferensial berdasarkan metode observasi spektofotometri yang menggunakan hukum beer-Lambert. Probe oksimetri terdiri dari dua diode pemancar cahaya light emitting Diode (LED) satu merah dan yang lainnya infra merah yang mentransmisikan cahaya melalui kuku jari, vena, darah arteri melalui foto detektor yang diletakkan didepan LED. LED pada foto detektor melewati bagian tubuh pasien mengirimkan cahaya infra merah sehingga dapat menembus jaringan tubuh, kemudian sinyal singkat saturasi oksigen akan dideteksi oleh fotoreceptor sehingga prosentase saturasi oksigen dan denyut nadi dapat ditampilkan.

Alat oksimetri nadi yang digunakan adalah alat oksimetri nadi yang sudah tersambung pada alat monitor dimasing-masing tempat tidur pasien dipasang pada ibu jari kanan tetapi bila tidak memungkinkan dipasang pada pada ibu jari kiri. Pengukuran saturasi oksigen dilakukan sebelum hiperoksigenasi dan setelah 1menit hiperoksigenasi. Alat oksimetri nadi ini dikalibrasi satu tahun sekali, namun bila ada kerusakan atau error akan langsung diperbaiki. Kalibrasi terakhir dilakukan bulan Maret tahun 2018. Oksimetri Nadi digunakan untuk mengukur kadar saturasi oksigen, hasil pengukuran dibaca pada layar monitor alat dengan waktu 3 detik. Hasil ukur dinyatakan dalam \%, data dideskripsikand alam bentuk numerik yang dinyatakan dengan penghitungan nilai mean, nilai median, dan simpangan baku, serta nilai minimal dan maksimal dan $95 \%$ confident interval mean.

\section{Hiperoksigenasi Intervensi I}

Tindakan hiperoksigenasi pada intervensi I menggunakan modus Syncronized Intermitten Mandatory Ventilator (IMV/SIMV) dengan suctionsystem terbuka, caranya adalah: sebelumnya mengidentifikasi nilai saturasi oksigen, hiperoksigenasi dengan cara meningkatkan aliran oksigen $100 \%$ pada kompresor dengan menekan tombol ventilator. Hiperoksigenasi pre suction diberikan 30 detik, dilakukan suction 10 detik, kemudian kembali ke pemberian ventilator semula, diberikan hiperoksigenasi kembali 30 detik (jeda antara suction lamanya 2 menit). Saturasi oksigen diidentifikasi sebelum hiperoksidenasi dan setelah hiperoksigenasi 1 menit. Alat ventilator ini dikalibrasi setiap tahun sekali, namun bila ada error akan langsung diperbaiki. Kalibrasi terakhir 
dilakukan bulan Maret tahun 2018 dengan lebel dikalibrasi Maret 2018 digantung pada mesin ventilator.

\title{
Intervensi II
}

Tindakan hiperoksigenasi pada intervensi II menggunakan modus Syncronized Intermitten Mandatory Ventilator (IMV/SIMV) dengan suctionsystem terbuka, caranya adalah: sebelumnya mengidentifikasi nilai saturasi oksigen, hiperoksigenasi dengan cara meningkatkan aliran oksigen $100 \%$ pada kompresor dengan menekan tombol ventilator. Hiperoksigenasipre suction diberikan 2 menit, dilakukan suction 15 detik, kemudian kembali ke pemberian ventilator semula, saturasi oksigen diidentifikasi. Alat ventilator ini dikalibrasi setiap tahun sekali, namun bila ada error akan langsung diperbaiki. Kalibrasi terakhir dilakukan bulan Maret tahun 2018 dengan lebel dikalibrasi Maret 2018 digantung pada mesin ventilator.

\begin{abstract}
Alat Suction
Alat suction yang digunakan adalah alat suction yang sudah menempel pada dinding tempat tidur pasien menggunakan sistem terbuka. Perawat melepas ventilator dan melakukan suction memasang kembali ventilator dan membuang kateter penghisap. Pada pelaksanaan suction, harus selalu diingat untuk memperhatikan besarnya ukuran dan tekanan saction sesuai usia. Alat suction ini dikalibrasi setiap tahun sekali, namun bila ada error akan langsung diperbaiki. Kalibrasi terakhir dilakukan bulan Maret tahun 2018 dengan lebel dikalibrasi Maret 2018 digantung pada mesin ventilator.
\end{abstract}

\section{Prosedur Pengumpulan Data}

Pada penelitian ini, teknik pengumpulan data yang dilakukan menggunakan cara dengan melakukan pemeriksaan saturasi oksigen terhadap responden. Caranya dengan membagi responden menjadi kelompok intervensi I dan kelompok Intervensi II.

Kedua kelompok dilakukan pemeriksaan awal yaitu pemeriksaan saturasi oksigen. Kelompok intervensi I tahap selanjutnya dilakukan intervensi dengan tindakan penelitian menggunakan modus Syncronized Intermitten Mandatory Ventilator (IMV/SIMV) dengan suction system terbuka, caranya adalah: sebelumnya mengidentifikasi nilai saturasi oksigen, selanjutnya melakukan hiperoksigenasi dengan cara meningkatkan aliran oksigen $100 \%$ pada kompresor dengan menekan tombol ventilator. Hiperoksigenasi pre suction diberikan 30 detik, kemudian dilakukan suction 10 detik, kembali ke pemberian ventilator semula, selanjutnya hiperoksigenasi kembali 30 detik (jeda antara suction lamanya 2 menit). Saturasi oksigen diidentifikasi sebelum hiperoksidenasi, dan setelah hiperoksigenasi 1 menit.

Sedangkan pada kelompok intervensi II mencatat nilai saturasi oksigen setelah tindakan suction yang dilakukan sesuai kebiasaan ruangan tersebut, yaitu sebelumnya mengidentifikasi nilai saturasi oksigen, selanjutnya melakukan hiperoksigenasi dengan cara meningkatkan aliran oksigen $100 \%$ pada kompresor dengan menekan tombol ventilator. Hiperoksigenasi pre suction diberikan 2 menit, dilakukan suction 15 detik, selanjutnya melihat ke nilai saturasi oksigen. 


\section{HASIL PENELITIAN}

\section{Analisis Univariat}

Karakteristik Responden

Tabel. 1

Distribusi Frekuensi Berdasarkan Karakteristik Responden pada Pasien Terpasang Ventilator $(n=34)$

\begin{tabular}{lcccc}
\hline \multicolumn{1}{c}{ Variabel } & \multicolumn{2}{c}{ Intervensi I } & \multicolumn{2}{c}{ Intervensi II } \\
\hline Usia & $\mathrm{n}$ & $\%$ & $\mathrm{n}$ & $\%$ \\
18-50 tahun & 5 & 29,4 & 5 & 29,4 \\
$>51$ tahun & 12 & 70,6 & 12 & 70,6 \\
\hline Jenis Kelamin & & & & \\
Laki & 12 & 70,6 & 8 & 47,1 \\
Perempuan & 5 & 29,4 & 9 & 52,9 \\
& & & & \\
Pekerjaan & 10 & 58,8 & 11 & 64,7 \\
Wiraswasta & 5 & 29,4 & 3 & 17,6 \\
ABRI/PNS & 2 & 11,8 & 3 & 17,6 \\
Purnawirawan/pensiun & & & & \\
\hline Kadar Hb & 3 & 17,6 & 1 & 5,9 \\
Normal & 14 & 82,4 & 16 & 94,1 \\
Anemia & & & & \\
\hline Nadi Perifer Pre & 3 & 17,6 & 8 & 47,1 \\
Normal & 14 & 82,4 & 9 & 52,9 \\
Tidak Normal & & & & \\
\hline Nadi Perifer Post Suction & 8 & 47,1 & 8 & 47,1 \\
Normal & 9 & 52,9 & 9 & 52,9 \\
Tidak Normal & & & &
\end{tabular}

Berdasarkan tabel 1 menunjukkan bahwa usia terbanyak pada kelompok intervensi I yaitu usia $>51$ tahun sejumlah 12 orang $(70,6 \%)$ dan usia 18-50 tahun sejumlah 5 orang $(29,4 \%)$. Sedangkan pada kelompok intervensi II usia terbanyak pada rentang $>51$ tahun sejumlah 12 orang $(70,6 \%)$ dan usia 18-50 tahun sejumlah 5 orang $(29,4 \%)$. Hal ini dapat disimpulkan bahwa responden terbanyak dalam penelitian ini adalah responden dengan usia $>51$ tahun. Sedangkan menurut jenis kelamin terbanyak pada kelompok intervensi I yaitu laki-laki sejumlah 12 orang $(70,6 \%)$ dan perempuan sejumlah 5 orang $(29,4 \%)$. Sedangkan pada kelompok intervensi II jenis kelamin lakilaki sejumlah 8 orang $(47,1 \%)$ dan perempuan sejumlah 9 orang $(52,9 \%)$. Hal ini dapat disimpulkan bahwa responden terbanyak dalam penelitian ini adalah responden dengan jenis kelamin laki-laki. Pekerjaan terbanyak pada kelompok intervensi I yaitu wiraswasta sejumlah 10 orang $(58,8 \%)$ Sedangkan pada kelompok II pekerjaan terbanyak yaitu wiraswasta sejumlah 11 orang $(64,7 \%)$. Hal ini dapat disimpulkan bahwa responden terbanyak dalam penelitian ini adalah responden dengan jenis kelamin laki-laki.

Kategori anemia pada kelompok intervensi I sejumlah 14 orang $(82,4 \%)$ dan kategori tidak anemia sejumlah 3 orang $(17,6 \%)$. Sedangkan pada kelompok intervensi II kategori anemia sejumlah 16 orang $(94,1 \%)$ dan kategori tidak anemia sejumlah 1 orang $(5,9 \%)$. Hal ini menyimpulkan bahwa responden terbanyak dalam penelitian ini adalah responden dengan kategori anemia. Nadi perifer responden tidak normal sebelum intervensi I sejumlah 14 orang $(82,4 \%)$ dan nadi perifer normal sejumlah 3 orang $(17,6 \%)$. Setelah intervensi nadi perifer responden tidak normal 9 orang $(52,9 \%)$ dan 
nadi perifer normal sejumlah 8 orang $(47,1 \%)$. Sedangkan pada kelompok intervensi II nadi perifer responden tidak normal sejumlah 9 orang $(52,9 \%)$ dan nadi perifer responden normal 8 orang $(47,1 \%)$. Setelah dilakukan ontervensi nadi perifer responden tidak mengalami perubahan dari sebelumnya. Hal ini dapat di simpulkan nadi perifer responden pada kelompok intervensi I mengalami perubahan kearah normal. Sedangkan pada kelompok intervensi II sebelum dan sesudah tidak mengalami perubahan.

Tabel. 2

Rata - Rata Nilai Saturasi Oksigen Sebelum dan Setelah Pemberian Hiperoksigenasi pada Kelompok Intervensi I dan Intervensi II $(n=34)$

\begin{tabular}{lcccc}
\hline \multicolumn{1}{c}{ Kelompok } & Mean & SD & Min-Mx & CI 95\% \\
\hline Intervensi I & & & & \\
Sebelum & 97,06 & 0,97 & $95-99$ & $96,56-97,56$ \\
Setelah & 98,88 & 0,78 & $98-100$ & $98,88-99,28$ \\
\hline Intervensi II & & & & \\
Sebelum & 97,65 & 1,32 & $95-100$ & $96,97-98,33$ \\
Setelah & 98,59 & 0,79 & $97-100$ & $98,18-99,00$ \\
\hline
\end{tabular}

Berdasarkan tabel 2 menunjukkan bahwa rata-rata saturasi oksigen pada kelompok intervensi I sebelum hiperoksigenasi yaitu 97,06 dengan standar deviasi 0,97 dan setelah pemberian hiperoksigenasi 1 menit rata-rata saturasi oksigen 98,88 dengan standar deviasi 0,78. Sedangkan pada kelompok intervensi II rata-rata saturasi oksigen sebelum hiperoksigenasi yaitu 97,65 dengan standar deviasi 1,32 dan setelah pemberian hiperoksigenasi rata-rata saturasi oksigen yaitu 98,59 dengan standar deviasi 0,79. Hal ini dapat disimpulkan bahwa terdapat peningkatan saturasi oksigen sebelum dan setelah pemberian hiperoksigenasi pada proses suction pada kelompok intervensi I dan intervensi II.

\section{Analisis Bivariat}

Tabel. 3

Perbedaan Nilai Saturasi Oksigen dengan Pemberian Hiperoksigenasi pada Proses Suction pada Kelompok Intervensi dan Kontrol $(\mathrm{n}=34)$

\begin{tabular}{|c|c|c|c|}
\hline Variabel & $\mathrm{n}$ & CI $95 \%$ & P Value \\
\hline \multicolumn{4}{|l|}{ Intervensi I } \\
\hline Sebelum & 17 & $96,56-97,56$ & $0,000 *$ \\
\hline Setelah & 17 & $98,48-99,28$ & \\
\hline Selisish & & $1,50-2,15$ & \\
\hline \multicolumn{4}{|l|}{ Intervensi II } \\
\hline Sebelum & 17 & $96,97-98,33$ & 0,009 \\
\hline Setelah & 17 & $98,18-99,00$ & \\
\hline Selisih & & $0,38-1,50$ & \\
\hline
\end{tabular}

Berdasarkan tabel 3 perbandingan pemberian hiperoksigenasi sebelum dan setelah hiperoksigenasi 1 menit pada kelompok intervensi I. Terdapat 17 responden dengan hasil peningkatan saturasi oksigen setelah diberikan hiperoksigenasi. Terlihat median saturasi oksigen kelompok intervensi I sebelum pemberian hiperoksigenasi yaitu 97 dengan mi-mak 95-100 dan setelah diberikan hiperoksigenasi 1 menit median 99 dengan min-mak 98-100. Selisih saturasi oksigen pada kelompok intervensi yaitu dengan median 2 min-mak 1-3. Hasil uji statistik diperoleh $\mathrm{p}$ value $0,000^{*}$ yang artinya 
terdapat berbedaan yang bermakna peningkatan nilai saturasi oksigen sebelum dan sesudah diberikan hiperoksigenasi 1 menit pada kelompok intervensi I. Sedangkan kelompok intervensi II dengan pemberian hiperoksigenasi terdapat 2 responden dengan penurunan saturasi oksigen, 1 responden dengan saturasi oksigen tetap dan 14 responden dengan peningkatan saturasi oksigen. Terlihat median saturasi oksigen sebelum dilakukan intervensi 97 dengan min-mak 95-100 dan setelah dilakukan intervensi sebesar 99 dengan min-maks 95-100. Selisih saturasi oksigen pada kelompok intervensi II yaitu dengan median 1 min-mak -2-2. Hasil uji statistic didapatkan nilai $\mathrm{p}=$ $0,009 *(<0,05)$ yang berarti terdapat perbedaan yang bermakna antara saturasi oksigen sebelum dan setelah diberikan hiperoksigenasi I pada kelompok intervensi II.

Tabel. 4

Perbedaan Nadi Perifer Sebelum dan Setelah Pemberian Hiperoksigenasi pada Proses Suction pada Kelompok Intervensi I dan Intervensi II $(\mathrm{n}=34)$

\begin{tabular}{ccccc}
\hline Variabel & & \multicolumn{2}{c}{ NP Post intervensi I } & P value \\
\hline \multicolumn{1}{c}{ Pre } & & Normal & Tidak Normal & \\
\hline Intervensi & Normal & $2(66,7 \%)$ & $1(33,3 \%)$ & 0,125 \\
\multicolumn{1}{c}{ I } & Tidak Normal & $6(42,9 \%)$ & $8(57,1 \%)$ & \\
\hline Intervensi & Normal & $8(50,0 \%)$ & $0(0,0 \%)$ & 1,000 \\
II & Tidak Normal & $0(0,0 \%)$ & $9(50,0 \%)$ & \\
\hline
\end{tabular}

Berdasarkan tabel 4 menunjukan nadi perifer pada kelompok intervensi I, sebelum hiperoksigenasi terdapat 3 orang nadi perifer normal, 14 orang nadi perifer tidak normal. Setelah dilakukan pemberian hiperoksigenasi 1 menit nadi perifer responden normal sebanyak 8 orang dan tidak normal 9 orang. Hasil uji statistik diperoleh p value 0,125 yang artinya tidak ada perbedaan yang bermakna antara nadi perifer sebelum dan setelah pemberian hiperoksigenasi 1 menit pada kelompok intervensi I. Sedangkan pada kelompok intervensi II sebulum dilakukan intervensi sebanyak 8 orang nadi perifer normal dan 9 orang nadi perifer tidak normal, setelah dilakukan pemberian hiperoksigenasi nadi perifer normal sebanyak 8 orang dan tidak normal 9 orang. Hasil uji statistik diperoleh $\mathrm{p}$ value 1,000 yang artinya tidak ada perbedaan yang bermakna antara nadi perifer sebelum dan setelah pemberian hiperoksigenasi pada kelompok intervensi II.

Tabel. 5

Perbedaan Nilai Saturasi Oksigen Sesudah Hiperoksigenasi pada kelompok Intervensi dan Kontrol $(\mathrm{n}=34)$

\begin{tabular}{cc}
\hline \multicolumn{2}{c}{ Sesudah hiperoksigenasi intervensi I } \\
\hline Sesudah Hiperoksigenasi & $\mathrm{r}=0,210$ \\
inervensi II & $\mathrm{p}=0,418$ \\
& $\mathrm{n}=34$ \\
\hline
\end{tabular}

Berdasarkan tabel 5 menunjukkan tidak ada perbedaan yang bermakna antara kelompok intervensi I (dengan pemberian hipeorksigenasi 1 menit) dan kelompok intervensi II (dengan pemberian hiperoksigenasi 2 menit) dengan $p$ value 0,418 dengan r 0,21 . 


\section{PEMBAHASAN}

\section{Karakteristik Responden}

Hasil penelitian usia menunjukkan bahwa sebagian besar responden pada kedua kelompok intervensi I dan II adalah responden dengan usia > 51 tahun sejumlah 24 responden dari 34 responden. Pada kelompok intervensi I sejumlah 12 orang $(70,6 \%)$ dan kelompok intervensi II 12 orang (70,6\%).

Menurut Kozier \& Erb (2012) Faktor-faktor yang mempengaruhi fungsi pernafasan adalah usia; perubahan yang terjadi karena penuaan mempengaruhi sistim pernafasan seringkali akibat adanya infeksi, emosional atau stress fisik, tindakan pembedahan, tindakan anesthesia, atau karena prosedur lainnya. Perubahan karena penuaan menyebabkan dinding dada dan juga jalan nafas menjadi kaku dan kurang elastic, jumlah pertukaran udara menjadi menurun, reflek batuk dan kerja silia menjadi lebih berkurang, membrane pada mukosa menjadi lebih kering dan juga lebih rapuh, terjadi penurunan kekuatan otot dan daya tahan tubuh, bilamana terjadi osteoporosis maka keadekuatan ekspansi pada paru dapat menurun, terjadi penurunan efisiensi sistim imunitas, dan karena penyakit refluks gastroesofagus lebih sering terjadi pada lansia atau akibat penuaan dan meningkatkan kejadian aspirasi dimana aspirasi lambung seringkali menyebabkan bronkopasme dengan menimbulkan respons imflamasi. Berdasarkan uraian diatas peneliti dapat menyimpulkan bahwa usia sangat mempengaruhi fungsi paru, ini dikerenakan dengan meningkatya usia kapasitas dinding paru dan juga jalan nafas menjadi kaku dan kurang elastis, membrane mukosa menjadi kering dan rapuh.

Hasil penelitian berdasarkan jenis kelamin menunjukkan bahwa pada kelompok intervensi I maupun kelompok intervensi II didapatkan hasil yang berbeda yaitu pada kelompok intervensi I sebagian besar responden dengan jenis kelamin laki-laki 12 orang $(70,6 \%)$ dari 17 responden. Pada kelompok intervensi II sebagian besar responden dengan jenis kelamin perempuan 9 orang $(52,9 \%)$ dari 17 responden. Menurut Kozier \& Erb (2012) teori jenis kelamin dikaitkan dengan kondisi pembuluh darah. Factor resiko berkurangnya suplai oksigen yang disebabkan oleh perokok yang banyak dilakukan oleh jenis kelamin laki-laki. Akibat rokok dapat menyebabkan penyakit jantung coroner akibat dari arteresklerosis.

Hasil penelitian berdasarkan pekerjaan menunjukkan bahwa pada kelompok intervensi I maupun kelompok intervensi II didapatkan pasien yang dilakukan tindakan suction pada pasien terpasang ventilator mayoritas pekerjaan responden adalah wiraswasta sebanyak 21 orang dari 34 responden. kelompok intervensi I sebanyak 10 orang $(58,8 \%)$ dan kelompok intervensi IIsebanyak 11 orang ( 64,7\%).

Responden dari penelitian ini banyak terdiagnosis karena pneumonia. Pekerjaan responden terbanyak adalah wiraswasta, hal ini berkaitan dengan nutrisi yang kurang sehingga menyebabkan terjadinya penurunan imunitas (Hudak \& Gallo, 2013). Hasil penelitian nilai HB menunjukkan bahwa sebagian besar responden pada kedua kelompok dengan kategori anemia sejumlah 30 orang dari 34 responden dengan intervensi I 14 orang $(82,4 \%)$ dan kelompok intervensi II 16 orang $(94,1 \%)$.

Setelah difusi dan ventilasi dari proses pernafasan melibatkan transport gas pernafasan, yaitu oksigen perlu di antar dari paru-paru ke jaringan, dan begitu pula dengan karbondioksida harus diantar dari jaringan tubuh kembali keparu-paru. Normalnya oksigen kisaran $97 \%$ berikatan dengan hemoglobin didalam sel darah merah dan dibawa menuju kejaringan sebagai oksihemoglobin. Berbagai faktor yang mempengaruhi kecepatan transport oksigen dari paru kejaringan adalah curah jantung, 
jumlah eritrosit dan hematokrit darah, serta olahraga dan latihan (Kozier \& Erb, 2012). Setiap kondisi patologis yang mengurangi curah jantung seperti misalnya kerusakan otot jantung, kehilangan darah, atau pengumpulan darah dipembuluh darah perifer dapat mengurangi jumlah oksigen yang dihantarkan kejaringan. Pada pria jumlah eritrosit yang beredar normalnya kisaran 5 juta permili meter kubik darah, hematokrit berkisar 40 sampai dengan $54 \%$. Sedangkan pada wanita berkisar 4,5 juta permili meter kubik darah, hematokrit berkisar 37 sampai dengan $48 \%$. Bila hematokrit ada peningkatan yang berlebihan maka akan terjadi vikositas pada darah, mengurangi curah jantung dan secara otomatis mengurangi transport oksigen (Kozier \& Erb, 2012).

Hasil penelitian nadi perifer menunjukkan bahwa sebelum intervensi sebagian besar responden pada kedua kelompok dengan nilai nadi perifer tidak normal ( $<60$ dan $>100 \mathrm{x} /$ menit) sebanyak 23 orang dari 34 responden. Responden dengan nadi perifer tidak normal ( $<60$ dan $>100 \mathrm{x} /$ menit) pada kelompok intervensi I 14 orang $(82,4 \%)$. Pada kelompok intervensi II nadi perifer tidak normal ( $<60$ dan $>100 \mathrm{x} /$ menit $) 9$ orang $(52,9 \%)$. Sedangkan setelah intervensi nadi perifer tidak normal ( $<60$ dan $>100 \mathrm{x} /$ menit) sebanyak 18 orang ( 2 kelompok) dari 34 responden. Responden dengan nadi perifer tidak normal ( $<60$ dan $>100 \mathrm{x} /$ menit) pada kelompok intervensi I 9 orang $(52,9 \%)$ kelompok intervensi II nadi perifer tidak normal ( $<60$ dan $>100 \mathrm{x} /$ menit) 9 orang $(52,9 \%)$.

\section{Evaluasi Spo2 pada Kelompok Intervensi I dan Intervensi II}

Hasil penelitian menunjukan bahwa sejumlah 17 orang respoden terjadi peningkatan nilai saturasi oksigen setelah hiperoksigenasi 1 menit pada kelompok intervensi I. Sedangkan pada kelompok intervensi II terdapat 14 orang peningkatan saturasi oksigen, 2 orang penurunan saturuasi oksigen dan 1 orang tetap pada pemberian Hiperoksigenasi. Hasil uji staitistik diperoleh p value 0,000* dan 0,009 yang artinya terdapat perbedaan yang bermakna terhadap nilai saturasi oksigen sebelum dan sesudah pemberian hiperoksigenasipada kedua kelompok. Berdasarkan hasil analisis pada tabel 5.7 menunjukan tidak ada perbedaan yang bermakna antara kelompok intervensi I (dengan pemberian hiperoksigenasi 1 menit) dan kelompok intervensi II (dengan pemberian hiperoksigenasi 2 menit). dengan $p$ value 0,418 dengan r 0,210. Artinya sama pemberian hiperoksigenasi 1 menit dengan 2 menit.

Penelitian yang dilakukan Moraveji et al., (2012) di ICU menunjukkan bahwa hiperoksigenasi yang dilakukan satu menit selama suction menyebabkan perbaikan dan pencegahan hipoksia yang disebabkan prosedur suction. Menurut Hudak \& Gallo (2013) mengatakan komplikasi dari pemberian oksigen adalah : membrane mukosa menjadi kering, epistaksis, atau infeksi pada lubang hidung. Bila dalam waktu lama dapat menyebabkan toksisitas yang tinggi (dapat dilihat pada kasus cedera paru akut atau sindrom pada gawat nafas akut), atelectasis absorbtif.

Menurut Hudak \& Gallo (2013) pemberian hiperoksigenasi yang berlebihan mempunyai efek samping. Bila dalam waktu lama dapat menyebabkan toksisitas yang tinggi (dapat dilihat pada kasus cedera paru akut atau sindrom pada gawat nafas akut), atelectasis absorbtif. Selain itu dapat terjadi narcosis karbondioksida dengan manifestasi perubahan status mental, konfusi, sakit kepala, dan somnolen. Pemberian hiperoksigenasi maksimal diberikan selama 2 menit pada tindakan suction.

Saturasi oksigen adalah nilai rasio jumlah $\mathrm{O}_{2}$ terikat pada hemoglobin pada kemampuan seluruh hemoglobin dapat berikatan dengan $\mathrm{O}_{2}$ (Hudak \& Gallo, 2013). nilai dari saturasi oksigen normalnya berkisar 95 sampai dengan $100 \%$ (walaupun 
pengukuran yang lebih rendah mungkin normal pada beberapa pasien, misalnya pada pasien PPOK (Fox, 2002). Saturasi oksigen dapat diukur dengan metode invasive maupun non invasive. Pengukuran dengan metode invasive menggunakan analisa gas darah. Adapun pengukuran metode non invasive menggunakan oksimetri nadi (Kozier \& Erb, 2012).

Pada saat akan melakukan tindakan suction pada ETT, sangatlah perlu adanya pemantauan saturasi oksigen, karena saat tindakan suction bukan hanya sekret yang terhisap, tetapi oksigen juga terhisap. Selain itu saturasi oksigen pada tindakan suction dipengaruhi oleh banyaknya hiperoksigenasi yang diberikan, tekanan suction yang sesuai usia, dan besar diameter kanule. Bila hal tersebut tidak atau kurang diperhatikan maka akan menimbulkan komplikasi. Komplikasi dari suction pada pasien yang terpasang ventilasi mekanik adalah terjadinya hipoksia yang ditandai dengan penurunan saturasi oksigen atau desaturasi (Kozier \& Erb, 2012). Menurut Wiyoto (2010) apabila suplai oksigen dalam waktu 4 menit tidak terpenuhi untuk suplai keotak maka otak terjadi kerusakan yang permanen, karena itu perlu dilakukan hiperoksigenasi sebelum dilakukan suction. Upaya untuk mempertahankan saturasi oksigen setelah dilakukan suction adalah dengan melakukan hiperoksigenasi pada setiap tindakan suction.

Untuk menghindari terjadinya hipoksemi dari prosedur suctioning sangat perlu dilakukan tindakan hiperoksigenasi. Hiperoksigenasi harus dilakukan pada setiap tindakan suctioning dengan cara meningkatkan aliran oksigen $100 \%$ melalui ventilator mekanik. Hiperoksigenasi merupakan tehnik yang terbaik harus dilakukan untuk meningkatkan nilai saturasi oksigen pada setiap prosedur suction (Kozier \& Erb, 2012).

Pada tindakan suction terjadi komplikasi yang dapat timbul diantaranya salah terjadinya hipoksemia atau hipoksia. Pada proses dilakukan penghisapan tidak hanya sekret yang terhisap, tetapi $\mathrm{O}_{2}$ juga terhisap dan menyebabkan kejadian hipoksemia yang terjadi sesaat dengan tanda penurunan nilai saturasi oksigen atau $\mathrm{SpO}_{2}$ (Saskatoon health Regional Authority, 2010) Dalam hal ini diperlukan tindakan hiperoksigenasi sebelum tindakan suction (Brunner \& Suddarth, 2012). Hiperoksigenasi harus dilakukan pada setiap tindakan suctioning dengan cara meningkatkan aliran oksigen $100 \%$ melalui ventilator mekanik. Hiperoksigenasi merupakan tehnik yang terbaik harus dilakukan untuk meningkatkan nilai saturasi oksigen pada setiap prosedur suction (Kozier \& Erb, 2012).

\section{SIMPULAN}

Hasil penelitian karaktristik responden dalam penelitian ini berdasarkan usia terbanyak pada usia >51 tahun, jenis kelamin laki-laki, pekerjaan wiraswasta hasil penelitian nilai $\mathrm{Hb}$ didapatkan bahwa sebagian besar respoden mempunyai nilai $\mathrm{Hb}$ dibawa normal. Hasil nadi perifer tidak ada perbedaan nilai nadi perifer sebelum dan sesudah intervensi pada masing-masing kelompok. Terdapat perbedaan yang bermakna terhadap nilai saturasi oksigen sebelum dan setelah intervensi hiper oksigenasipada kedua kelompok. Tidak terdapat perbedaan yang bermakna nilai saturasi oksigen sesudah intervensi hiperoksigenasi pada kedua kelompok.

\section{SARAN}

\section{Bagi Pelayanan Keperawatan}

Pemberian hiperoksigenasi 1 menit maupun 2 menit pada proses suction dapat dijadikan salah satu intervensi keperawatan mandiri untuk meningkatkan nilai saturasi oksigen pada pasien dengan gangguan bersihan jalan nafas yang terpasang ventilator 
terutama di intensive care unit RSPAD Gatot Soebroto PUSKESAD. Namun yang lebih efisien adalah pemberian hiperoksigenasi 1 menit. Berdasarkan hasil penelitian ini diharapkan perawat dapat meningkatkan pengetahuan terkait pemberian hiperoksigenasi Bagi manager keperawatan diharapakan dapat mempertimbangkan dan meberikan informasi dalam penyusunan rencana asuhaan keperawatan yang lebih baik lagi.

\section{Bagi Pendidikan Keperawatan}

Penelitian ini diharapkan dapat dijadikan sumber bagi perkembangan ilmu pengetahuan keperawatan khususnya yang terkait dengan pemberian hiperoksigenasi pada proses suction. Hasil penelitian ini diharapkan dapat dijadikan kajian ilmu bagi para pendidik dan mahasiswa sehingga dapat menambah wawasan.

\section{Bagi Penelitian Selanjutnya}

Penelitian ini bersifat aplikatif, diharapkan dapat dikembangkan lagi untuk memperkaya ilmu keperawatan terutama untuk intervensi keperawatan yang berkaitan dengan pemberian hiperoksignasi dengan lebih mengontrol factor counfounding dan juga membedakan waktu pemberian hiperoksigenasi.

\section{DAFTAR PUSTAKA}

American Association for Respiratory Care. (2010). Endotracheal Suctioning of Mechanically Ventilated Patients with Artificial Airways 2010, (Online),(http:// rcjournal.com/cpgs/pdf., diakses tanggal 12 Maret 2018)

Brunner, B., \& Suddarth, S. (2012). Buku Ajar Keperawatan Medikal Bedah Edisi 8 volume 2. Jakarta: EGC

Depkes RI. (2012). Profil Data Kesehatan Indonesia Tahun 2011. Jakarta: Kementrian Kesehatan RI

Fox, N. (2002). Pulse Oximetry. Nursing Times, 98, 65-67

Hudak, C. M., \& Gallo, B. M. (2013). Keperawatan Kritis: Pendekatan Holistik Volume 1 (Ed.6). (M. Ester, editor) (Asih, Penerjemah). Jakarta: EGC

ICU RSPAD. (2018). Laporan Tahunan ICU Tahun 2017 RSPAD Gatot Puskesad

Kementerian Kesehatan RI. (2012). 10 Penyakit Tidak Menular yang Menyebabkan Kematian Tahun 2010. Jakarta

Kozier, B., Erb, G., Berman, A., \& Snyder, S. (2012). Fundamental of Nursing: Concept, Process, and Practice. Editor Edisi Bahasa Indonesia: Widiarti, W. Buku Ajar Fundamental Keperawatan: Konsep, Proses, dan Praktik. Edisi 7. Vol. 1. Jakarta: EGC

Moraveji, M., Nezhad, S., \& Bazargan, M. (2012). Effect of Hyperoxygenation for One Minute on ABGs during Endotracheal Suctioning in ICU in Zanjan Vali- E-Asr Hospital. Life Science Journal, 10(9)

Musliha, M. (2010). Keperawatan Gawat Darurat. Jakarta: NuMed

Nurachmah, E., \& Sudarsono, R. S. (2010). Buku Saku Prosedur Keperawatan Medikal Bedah. Jakarta: EGC

Price, S. A., \& Wilson, L.,M. (2012). Patofisologi-Konsep Klinis Proses-Proses Penyakit, (edisi 6). alih bahasa Nike Esti Wahyuningsih. Jakarta: EGC

Saskatoon Health Region Authority (SHRA). (2010), June. Suctioning Artificial Airways in Adults. Paper Presented at the RN and LPN Learning Package, Saskatoon, SK 
Wijaya, W. (2015). Perubahan Saturasi Oksigen pada Pasien Kritis yang Dilakukan Tindakan Suction Endotracheal Tube di ICU RSUD Dr. Moewardi Surakarta

Wiyoto, W. (2010). Hubungan Tingkat Pengetahuan Perawat tentang Prosedur dalam Melakukan Tindakan Suction di ICU Rumah Sakit dr. Kariadi Semarang. diakses tanggal 13 Mar 2018 